Journal of Economics and Behavioral Studies (ISSN: 2220-6140)

Vol. 8, No. 5, pp. 27-38, October 2016

\title{
Structural Determinants of Job Satisfaction: The Mutual Influences of Compensation Management and Employees' Motivation
}

\author{
Abayomi Olarewaju Adeoye ${ }^{1 *}$, Sulaiman Olusegun Atiku² ${ }^{2}$ Ziska Fields ${ }^{1}$ \\ ${ }^{1}$ Lagos State University, Nigeria \\ 2University of KwaZulu-Natal, Westville Campus, Durban, South Africa \\ *eveyom@yahoo.com, Atiku@ukzn.ac.za, Fields@ukzn.ac.za
}

\begin{abstract}
The importance of job satisfaction as an antecedent to employees' productivity and firm outcomes cannot be overrated in the world of business, especially in the service industry. This paper adds to the understanding of job satisfaction in insurance business by investigating the structural causes of task fulfilment. The mutual influences of compensation administration and employees' motivation on job satisfaction was assessed using multivariate analysis. This research embraced a quantitative method and 212 employees were drawn using a convenience sampling technique. Three propositions were tested employing inferential statistical analyses run through SPSS statistics version 23 and SPSS Analysis of Moment Structures (AMOS) version 23. AMOS was used to structurally determine job satisfaction through structural equation modelling (SEM). SPSS statistics version 23 was instrumental in assessing the psychometric properties via exploratory factor analysis and Cronbach's alpha coefficients. The results indicate a substantial affiliation between reward administration and motivation. Statistically, this study found that compensation management exerts more direct influence on employees' job satisfaction than the indirect tie through motivation. There may be a need to redesign human resource practices in the industry to improve the degree of employees' gratification and duty fulfilment.
\end{abstract}

Keywords: Compensation management, Employees' motivation, Job satisfaction, Structural equation modelling

\section{Introduction}

Human resources could be referred to as one of the most valued assets in service organisations across the globe. Satisfaction of employees in any service organisation is necessary for their service delivery, customers' satisfaction and retention, organisational performance and sustainable competitive advantage. Hence, considerable attention must be given to the satisfaction of such a vital asset by the management in service organisations. Factors inducing job satisfaction have been mentioned by different authors, and they have been compartmentalized into twofold, job related factors and personality involved factors (Aydogdu \& Asikgil, 2011). According to authors, features related to work contentment include remuneration, the vocation, regulation, advancement, contemporaries and operating circumstances. Factors related to individual, on the other hand, are loyalty of individuals, experience, age, gender, and education. Similarly, Haque, Karim, Muqtadir and Anam (2012) argue that there are two factors affecting job satisfaction level of employees, namely are personal and organisational factors. To them, personal factors are age, gender, race and religious affiliation, and the organisational factors are leadership, organisational change and technological innovation, continuous professional development, recruitment, rotation and retention, work environment, communication and commitment, salary and stress. Lee and Way (2010) identified work itself, supervision and compensation as the overall factors influencing employees' job satisfaction in the service industry. However, employees' satisfaction in service organisations has not been fully investigated in Nigeria, specifically in the insurance industry (Adeoye \& Fields, 2014).

Balachandan, Panchanathan and Subramanian (2010) looked at the task fulfilment factors that stimulate workers of insurance companies (in private sector and government insurance companies). The study found that they were not influenced by motivational factors to the same degree as those in other institutions. Arshadi's (2010) established that self-sufficiency anticipates the fulfilment of three emotional requirements predicted by job inspiration and task execution in an industrial company in Iran. Ayeni and Popoola (2007) 
proved a correlation rapport amongst felt stimulus, work fulfilment and allegiance. Ayeni and Popoola's study on work motivation, job satisfaction and organisational commitment of library personnel in Nigeria, indicates a negative correlation concerning enthusiasm and steadfastness of the library workforce. Whether one can generalise this outcome as the true opinion of workers in all service industries in Nigeria suggests the rationale for the current study. To fill this gap, this paper strives to structurally analyse; examine and operationalise a model to measure job satisfaction in the insurance industry, exploring the mutual influences of compensation management and employees' motivation. A conceptual framework advanced by Adeoye (2014) is subsequently discussed drawing insights from the expectancy theory of motivation by Victor Vroom. Sections on methods used in testing and operationalising the proposed model, results, discussion of findings, conclusion and managerial relevance are provided.

\section{Literature Review}

This section offers a conceptual clarification on compensation management and employees' motivation in relation to job satisfaction. The mutual influences of pay and other forms of employees' motivation on job satisfaction in various sectors are explored, in order to develop a conceptual framework for further empirical analysis.

Compensation Management: Innumerable explanations have been bequeathed on compensation (Adeoye, 2014). Ordinarily, compensation is a form of remuneration awarded for a responsibility carried out or strength exerted to accomplish a target which assists as a motivational factor that emboldens an individual to put more vitality or commitment into his or her job (Armache, 2012; Ederer \& Manso, 2013; Qureshi, 2013). Generally, businesses major reason for reward is to spur the conducts of the worker in a specific manner. Consequently, a firm does not aim only to persuade staffs to stay in the organisation, but fortifies employees' effort via ample and inspiring benefit. The fundamentals of inspiration were stated as that which is imperative to an individual, advancing it as a replacement, and the preferred comportment (Milkovich \& Newman, 1999; Riddell, 2011; Shaw, 2014). Hills, Bergmann and Scarpello (1994, p. 11) express reward as "the total sum of wage or salary, employee benefits, non-recurring financial rewards and non-pecuniary rewards", Milkovich, Newman and Gerhart (2011, p. 10) describe remuneration as "all forms of financial returns on tangible services and benefits employees receive as part of an employment relationship". There is a resemblance among recompense administration, enthusiasm and job satisfaction which are the concepts of this inquiry and are greatly interrelated. Stringer, Didham and Theivananthampillai (2011) found that inspiration is definitely linked to remuneration contentment which in turn boosts the firms result in Australasia. They reiterated that the qualitative acumens show a mark of wage impartiality across contrasts by the participants. The participants believed that their reward do not complement efforts put in.

Motivation: The term 'motivation' connotes different ideas to diverse individuals, it was derived from the Latin word "movere" meaning to shift or alter (Adeoye, 2001). Mathauer and Imohoff (2006, p. 3) describe it as "the willingness to exert and maintain an effort towards organisational goals". Adeoye (2001, p. 46) reasons "it is an enticement to stimulate concentration of a worker to realise a definite organisational goal". Ahlstrom and Bruton (2010, p. 200) referred to it as "thrust for individual's exploits that rejuvenates and guides goal-oriented behaviour". Similarly, motivation is described as a propeller that strengthens behaviour, offers attitudinal path and inspires consistency as worker meets serious encounters (Grobler, Wärnich, Carrell, Elbert \& Hatfield, 2011; Mathis \& Jackson, 2011; Adeoye \& Elegunde, 2014; Brevis \& Vrba, 2014). Ramlall $(2004$, p. 53) coined it as "keenness to utilise extraordinary effort towards organisation's goals, conditioned by the efforts ability to satisfy some individual need". He also asserts that motivation represents "those psychological processes that cause the arousal, direction, and persistence of deliberate actions that are goal oriented". Mitchell, (1982, p. 81), Lin (2007, p. 137) and Seiler, Lent, Pinkowska and Pinazza (2011) saw it as "an internal driver that triggers and guide attitude". These authors stress it invigorates and channels behaviour in getting a particular goal and is deliberate and directional. Motivating employees is a factor to ensure cutting edge benefit in the global environment (Govender \& Parumasur, 2010).

Kulkarni (2011) debates' inspiring a worker is a big task for employers of labour. It is said that allegiance and devotion of a staff to the firm, department or crew, is a function of involvement of individual. Conversely, the 
link between spur, work or firm accomplishment and work contentment cannot be underrated. Kulkarni (2011) states inducement is a bid to activate firm's specifications that stimulates the worker's feeling toward the fulfilment of firms goals. However, intent of motivation is working out conditions upon which people have the willingness and persuasion to work with zeal, creativity, interest and preparedness to work without being monitored or supervised (Hewitt, 2009; Wininger \& Norman, 2010). In this regard, motivation is set to attain group morale, contentment with a sense of accountability, reliability, self-control, and dignity with total confidence in such a consistent manner that the aspirations of the organisation or firm are attainable in a proficient and valuable way (Bob, 2011). For the sake of this paper, intrinsic and extrinsic motivation will be considered.

Intrinsic enthusiasm means carrying out an activity for the sake of doing that activity, which implies that the pursuit is exciting, appealing and generates fulfilment. For example, the tolerability of an internet-based learning mode by students is anchored on comprehended amusement in using the new erudition method (Lee, Cheung \& Chen, 2005). Nigerian insurance industry could employ this to boost the functioning staffs by sending them on training. Also, innate inspiration stems up through knowledge sharing. Staffs find accomplishment in enriching their know-how, self-efficacy or self-confidence in providing expedient expertise to the firm to enhance the firm outcomes and their own outcomes (Lin, 2007; Cruz, Pérez \& Cantero, 2009). On the other hand, extrinsic enthusiasm is to satiate unintended desires or recognition for a well done task; for example, pay increases, praise and promotion. This is motivation that is based on the achievement of a desired goal or some other kind of peripheral reimbursement such as cash or prices (Walker, Greene \& Mansell, 2006). Lin (2007) suggested that extrinsic stimulus focuses on goal-oriented reasons like recompense or remuneration gotten when performing a responsibility. He claims combination of both inherent and extrinsic enthusiasm alters personal intents regarding an activity as well as their real manner. This is corroborated by Kim, Shim and Ahn (2011) who found that extrinsic stimulus deals with behaviours that are engaged in response to pursuits that are different from their own, e.g. disbursements or acknowledgement or the influences of other people. The finding is germane to this paper because without team work the expected outcome might not be feasible.

A linkage has been established among spur and outcome. Obviously, result is attained as workers are appropriately inspired, and in its real sense, inspiration cannot be disconnected from outcome since spur is an enticement resulting to a better outcome. Elisenberger and Aselage (2009) established a progressive connection amidst drive and outcome. This finding shows result of a study on remuneration for extraordinary act on experienced aftermath burden, inherent curiosity and inventiveness. Morrell (2011) established an association among non-monetary incentive as a form of motivation and output of the individual, thereby enhancing efficiency. Non-monetary spurs is not only encouraging workers engagement, it reduces firm's overhead or cost. Similarly, Manolopoulos (2008) discovered significant linkage within motivation and efficiency in the public sector of Greece. Larson, Latham, Appleby and Harshman (2012) reported a strong relationship between motivation and achieving performance excellence among CEO attitudes and motivation. Taking insights from the literature on compensation management and motivation, hypothesis one (H1) was formulated and subjected to statistical analysis.

H1 Compensation administration positively impact workers' motivation in the insurance business.

Job Satisfaction: is an essential tool to accomplish the expected workers' performance as well as organisational outcomes in the realm of work. Hence, it is a motivational aspect that arouses the interest of workers in their tasks to achieve firm's aims (Feinstein \& Vondrasek, 2000; Ahmed et al., 2010; Celik et al., 2011; Amila-Prasanga \& Gamage, 2012). In addition, work fulfilment is a features exhibited by individuals in relation to duties which could be referred to as a consequential result of different opinions vis-à-vis the work they do. It is a sensitive matter or evaluative element that establishes positive, neutral or negative feelings in an individual identified as attitudinal thing, or opinion emphasis (Ivancevich \& Matteson, 1990; Greenberg \& Baron, 2000; Aydogdu \& Asikgil, 2011). Similarly, Eren (1993) and Çelik et al. (2011) accentuate career fulfilment as exhibited manner of staffs as regards duties and as such it is a general manifestation of workers' attitudes. These attitudes are developed in respect of jobs and are based on different characteristics of the job in question, and they are in tandem with the status attained or earned relating to their jobs and the knowhow learnt through the job environment (Ceelik et al., 2011). Rashid, Wani and Kumar (2013) argue that job 
satisfaction and motivation are inseparable tangible principles when it comes to the issue of success of any firm and its workers. Thus, if workers are encouraged towards their job, they feel more satisfied in their jobs. Consequently, they offer their best effort and contribute their quotas towards the achievement of common goals and objectives. The following hypotheses were subjected to empirical analysis in this study.

H2: Motivation positively influenced workers' job contentment in the insurance industry.

H3: Compensation management has a positive bearing on workers' satisfaction in insurance business.

Theoretical Foundation: According to Adeoye (2014), several theories have been put forward in relation to compensation, motivation, and how these affect employee's job satisfaction. Some of the compensation theories are Jensen's (1994) agency theory, Adams's (1965) equity theory, Davidson's (1898) bargaining theory, the behavioural wage theory based on the work of Mayo (1930), and Vroom's (1964) expectancy theory of wage. Many motivational theories, such as Maslow's (1943) hierarchy of needs, Alderfer's (1972) existence, relatedness and growth (ERG) theory and Herzberg's (1966) two-factor theory, all under the content theory of motivation, have also been propounded. Adams's (1965) equity theory and Vroom's (1964) expectancy theory were extended by Porter and Lawler III (1968) in his Porter and Lawler's (1968) expectancy model. According to Kreitner and Kinicki (1998), the model identifies the source of people's valences and expectancies and link effort with feat and job fulfilment. The Porter and Lawler model considered effort as a function of the perceived value of a bonus and the perceived effort-reward probability. Ramlall (2004, p. 56) cites Porter and Lawler (1968) who argued "employees should exhibit more effort when they believe they will receive valued reward for task accomplishment. It is concluded that employees are more satisfied when they feel equitably rewarded. In addition, employees' future effort-reward probabilities are swayed by past experience with performance and rewards." The theoretical foundation for this paper was Porter and Lawler's (1968) expectancy model which is anchored on Vroom's (1964) expectancy theory of motivation that provides understandings on how compensation and motivation influence employees' job satisfaction. Putting this proposition to empirical test in the insurance industry in Nigeria, this paper seeks to structurally determine the mutual influences of compensation management and employees' motivation on workers satisfaction.

The Conceptual Framework: Adeoye (2014) created a conceptual framework to measure the association of compensation management with job satisfaction concentrating on the mediating influence of employees' motivation in the insurance industry in Nigeria. Figure 1 illustrates the conceptual framework.

\section{Figure 1: Conceptual framework}

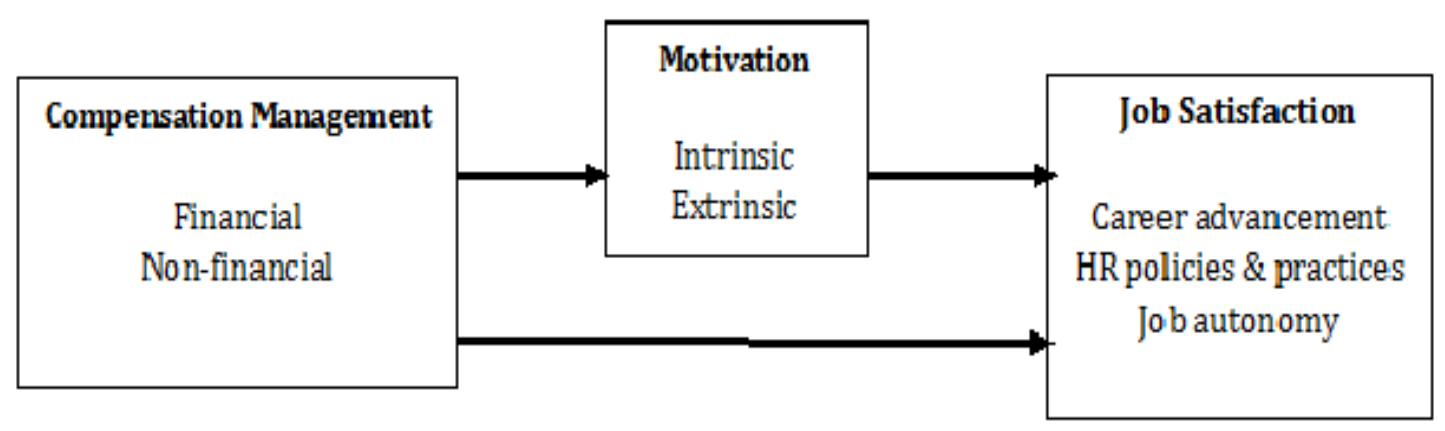

Source:

Adapted from Adeoye (2014)

As illustrated in Figure 1, compensation management and motivation are specified as exogenous latent variables (also see Figures 2 and 3). Job satisfaction is the endogenous latent variable in the measurement and structural models presented in Figures 2 and 3 respectively. Also, motivation could be referred to as a mediator in the link between compensation management and workers' satisfaction in the insurance industry. The corresponding exogenous and endogenous manifest variables are denoted with boxes in the measurement and structural models. 


\section{Methodology}

The main purpose of this paper was to structurally explore the influences of compensation management and employees' motivation on job satisfaction in insurance industry. To meet this objective, a quantitative approach was adopted, drawing insights from the principles of non-experimental and observational approaches. These approaches were combined because the researchers gave no priority for manipulation of the exogenous variables. The observational approach allowed the researchers to subject the variables to Confirmatory Factor Analysis (CFA) and Structural Equation Modelling (SEM).

Sample Procedure: Two hundred and fifty (250) structured questionnaires were administered to the staff of an insurance company operating in the south-western part of Nigeria. The respondents were selected based on the principle of convenience sampling. The self-administered questionnaires were distributed among all branches in the south-west, including the headquarters of the company situated in Lagos, Nigeria. After three months' extensive field work, 213 questionnaires were retrieved by the researchers. One of the survey instrument was not properly done by a respondent, thus it was later discarded at the preliminary data analysis stage. The remaining 212 questionnaires represented a response rate of $84.8 \%$.

Measures: The Compensation Management Questionnaire (CMQ) was developed on a 7-point Likert-type rating scale ranging from strongly disagree (1), disagree (2), slightly disagree (3), neutral (4), agree slightly (5), agree (6) to strongly agree (7), with six items. To measure motivation, the Motivation Questionnaire Scale (MQS) was adapted based on the motivation work of Mottaz (1985), Brislin et al. (2005), Altindis (2011), and Mahaney and Lederer (2006). The six items measuring motivation in the insurance industry were designed on a 7-point Likert-type rating scale ranging from strongly disagree (1) to strongly agree (7). Measuring job satisfaction in this study, the Minnesota Job Satisfaction Questionnaire (MSQ) was adapted. The short form of the MSQ consists of 20 items and three-dimensional scales: intrinsic satisfaction, extrinsic satisfaction, and general satisfaction, and is made up of a 5-point scale ranging from very dissatisfied (1) to very satisfied (5) (Weiss et al. 1967). Scores on the Intrinsic Satisfaction scale range from 0.84 to 0.91, scores on the Extrinsic Satisfaction scale range from 0.77 to 0.82 , while scores on the General Satisfaction scale range from 0.87 to 0.92. The reliability coefficients were $0.86,0.80$ and 0.90 for intrinsic satisfaction, extrinsic satisfaction and general satisfaction respectively (Weiss et al., 1967). The MSQ has been used in various Nigerian samples and it reported reliable alpha coefficient of 0.82 (Tella, Ayeni \& Popoola, 2007) and the internal consistency was between 0.82 and 0.93 (Gummi, 2011). In the current paper job satisfaction was measure using six items drafted on a 7-point Likert-type rating scale ranging from strongly disagree (1) to strongly agree (7). The Cronbach's alpha coefficients of the major constructs investigated in this study are presented after Exploratory Factor Analysis (EFA).

\section{Data Analysis and Results}

Two software packages were employed for data analysis. Statistical Package for the Social Sciences (SPSS) version 23 was used for the preliminary data analysis and the reliability of the research instrument. Statistical validity of the research instrument was assessed using EFA. A maximum likelihood was employed to extract the initial set of factors with an Oblique Promax Rotation using SPSS version 23. Items loading greater than 0.45 were considered significant based on the rule of thumb guiding significant factor loading and samples (MacCallum, Widaman, Zhang \& Hong, 1999). The cross-loaded items were deleted. These were items 4 on the scale measured compensation management, items 1 and 4 on the scale measured motivation, and items 1, 5 and 6 on the scale measured job satisfaction in the insurance industry. The psychometric property of the research instrument is presented in Table 1.

Three (3) factors were extracted judging from the pattern matrix and the total variance that has been explained. Factor 1, compensation management in the insurance industry emerged as one of the most crucial factor with a considerable variance of $40.6 \%$. This factor relates to salaries offered to employees by the management of the insurance companies in Nigeria. Factor 2, motivation, emerged as the second most important factor with a variance of $7.9 \%$. This factor assessed motivation using promotion, company policy, developmental programmes and equity in terms of employees' pay with their counterparts in similar 
industries. Factor 3, job satisfaction emerged as the third most important factor with a variance of 7.5\%. This factor points to opportunities for career advancement, work flexibility, and satisfaction with human resource policies and practices in the insurance industry. The Cronbach's alpha coefficients for compensation management, motivation and job satisfaction were $0.887,0.795$ and 0.735 respectively. It can be concluded that the research instrument used in measuring the major constructs are reliable based on the rule of thumb (Pallant, 2011). The correlation coefficients of the major variables are presented in Table 2.

Table 1: Psychometric properties of the research instrument

\begin{tabular}{lllll}
\hline $\begin{array}{l}\text { Items } \\
\text { Compensation management }\end{array}$ & Mean & SD & $\begin{array}{l}\text { Factor } \\
\text { loading }\end{array}$ & $\begin{array}{l}\text { Item total } \\
\text { correlation }\end{array}$
\end{tabular}

My salary is commensurate to the work I do.

My salary is above those paid by similar company in the industry.

My salary is enough to compensate me for my job in the company.

My salary is competitive, reasonable and is reviewed in a fair manner.

My company pays salary and emolument that are sufficient to motivate employees to perform effectively based on a lay down procedure.

\begin{tabular}{|c|c|c|c|c|}
\hline $\begin{array}{l}\text { Items } \\
\text { Motivation }\end{array}$ & Mean & SD & $\begin{array}{l}\text { Factor } \\
\text { loading }\end{array}$ & $\begin{array}{l}\text { Item total } \\
\text { correlation }\end{array}$ \\
\hline $\begin{array}{l}\text { My promotion is enhanced through what I do on the job or } \\
\text { have achieved. }\end{array}$ & 4.40 & 1.759 & .688 & .471 \\
\hline $\begin{array}{l}\text { The company policy is friendly and flexible in allowing } \\
\text { contribution of new ideas by an employee. }\end{array}$ & 3.76 & 1.684 & .668 & .636 \\
\hline $\begin{array}{l}\text { Developmental programmes have been used by the } \\
\text { organisation to boost employees' morale. }\end{array}$ & 3.53 & 1.638 & .771 & .519 \\
\hline $\begin{array}{l}\text { I received the same compensation as my counterparts in } \\
\text { similar industry. }\end{array}$ & 2.80 & 1.753 & .687 & .540 \\
\hline $\begin{array}{l}\text { Items } \\
\text { Job satisfaction }\end{array}$ & Mean & SD & $\begin{array}{l}\text { Factor } \\
\text { loading }\end{array}$ & $\begin{array}{l}\text { Item total } \\
\text { correlation }\end{array}$ \\
\hline The opportunities for advancement on this job & 4.52 & 1.552 & .800 & .414 \\
\hline The chances to be responsible to determine and plan my work & 4.38 & 1.535 & .544 & .463 \\
\hline The policies and practices toward employees of this company & 3.82 & 1.485 & .767 & .553 \\
\hline
\end{tabular}

Notes: $\mathrm{KMO}=0.869 ; \mathrm{X} 2=1$ 164.86; $\mathrm{Df}=66 ; \mathrm{P}<0.001 ;$ percentage of variance explained $=55.917 \%$ Source: Emerged from the statistical analysis

Table 2: Descriptive analysis and correlation coefficients among the variables

\begin{tabular}{llllll}
\hline & Variables & Mean & Std. Deviation & $\mathbf{1}$ & $\mathbf{2}$ \\
\hline 1 & Compensation management & 17.0550 & 7.46189 & & \\
2 & Motivation & 14.4875 & 5.37702 & $.593^{* *}$ & \\
3 & Job satisfaction & 12.7173 & 3.69502 & $.491^{* *}$ & $.378^{* *}$ \\
\hline$* *$
\end{tabular}

**. Correlation is significant at $\mathrm{p}<0.001$ level (2-tailed).

Source: Emerged from the statistical analysis

As evident in Table 2, all correlation coefficients among the variables were positive and significantly correlated $(\mathrm{p}<0.001)$. There was a moderate positive relationship between motivation and job satisfaction in the insurance industry $(\mathrm{r}=0.378, \mathrm{n}=212$ and $\mathrm{p}<0.001)$. The relationship between compensation management and motivation was strong and positively correlated $(\mathrm{r}=0.539, \mathrm{n}=212$ and $\mathrm{p}<0.001)$. This implies that a higher level of pay offered to employees by the management will boost the morale of employees in the insurance industry. There was a strong positive relationship between compensation 
management and employees' job satisfaction in the insurance industry $(r=0.491, n=212$ and $p<0.001)$. This means that an increase in the compensation package will also result in an increase in the opportunities for career advancement, satisfaction with HR policies and practices in the insurance industry.

Having conducted the EFA, statistical reliability and validity of the research instrument, as well as the bivariate correlation coefficients between the variables investigated. The latent variables (compensation management, motivation and job satisfaction) were subjected to further analysis using SPSS Analysis of Moment Structures (AMOS) version 23. This statistical package was instrumental in running the measurement model presented in Figure 3 and the structural model presented in Figure 4. The following model fit indices were used. The chi-square value, degree of freedom and P values of all factors or beta loadings were used to determine the model fit. In cases of large chi-square values and degree of freedoms, the normed chi-square test values were used, which is the chi-square value - degree of freedom ratio. Three incremental model fit indices were used to assess the model fit; the Tucker-Lewis Index (TLI), the Incremental Fit Index (IFI) and the Comparative Fit Index (CFI). The values for Gross Fit Index (GFI) and Root Mean Square Error of Approximation (RMSEA) were also reported in this paper to determine the fitness of the proposed model. The measurement model and the model fit indices are presented in Figure 3.

Figure 2: Measurement model for structural determinants of job satisfaction

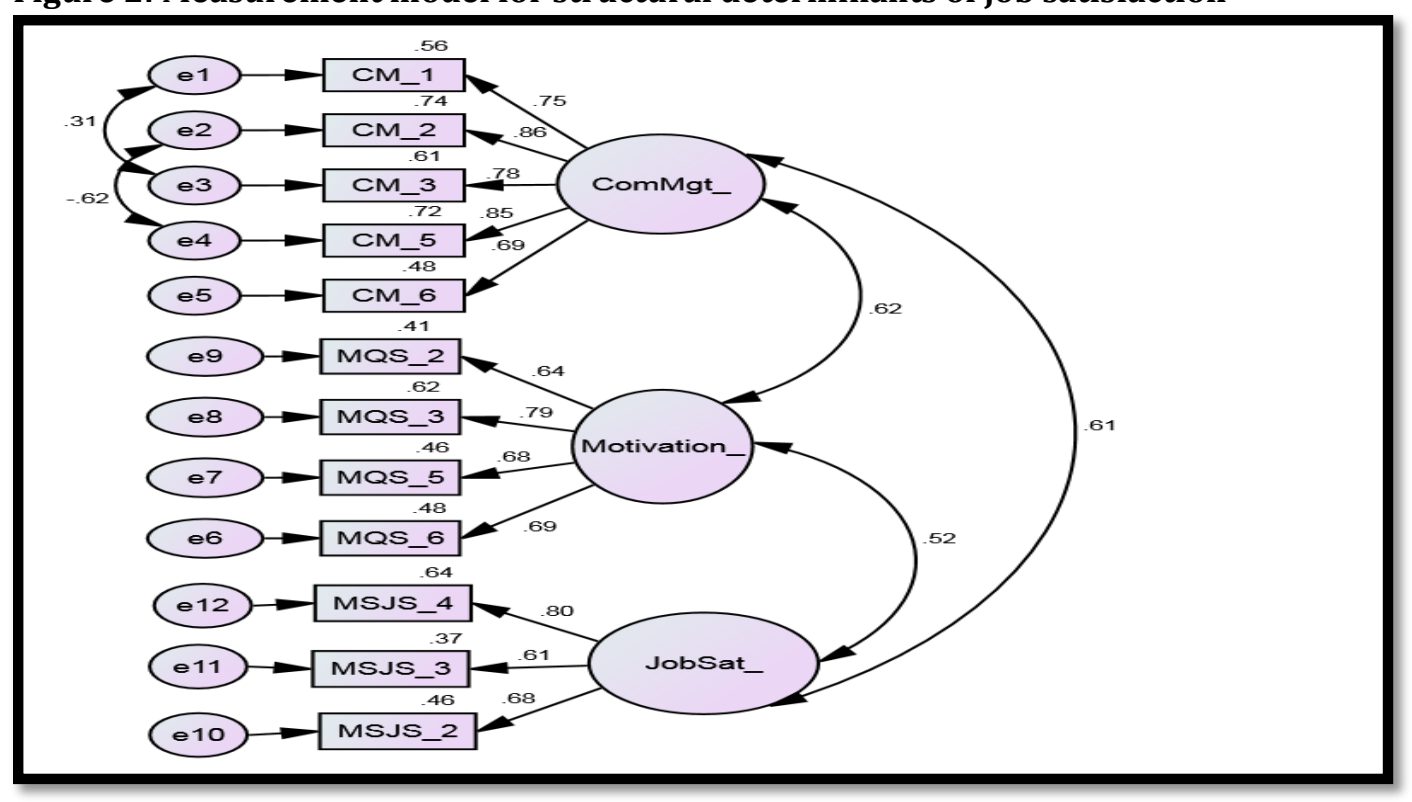

Chi-square $=95.276 ; \mathrm{DF}=49 ; \mathrm{p}$-value $=0.000(<0.001)$;

CMIN/DF = $1.944(<5) ; \mathrm{GFI}=0.937(>0.90)$;

$\mathrm{NFI}=0.920(>0.90) ; \mathrm{IFI}=0.960(>0.90) ; \mathrm{TLI}=0.945(>0.90) ; \mathrm{CFI}=0.959(>0.90) ; \mathrm{RMSEA}=0.067$ (below $0.08)$ 
Figure 3: Structural model for job satisfaction in the insurance industry

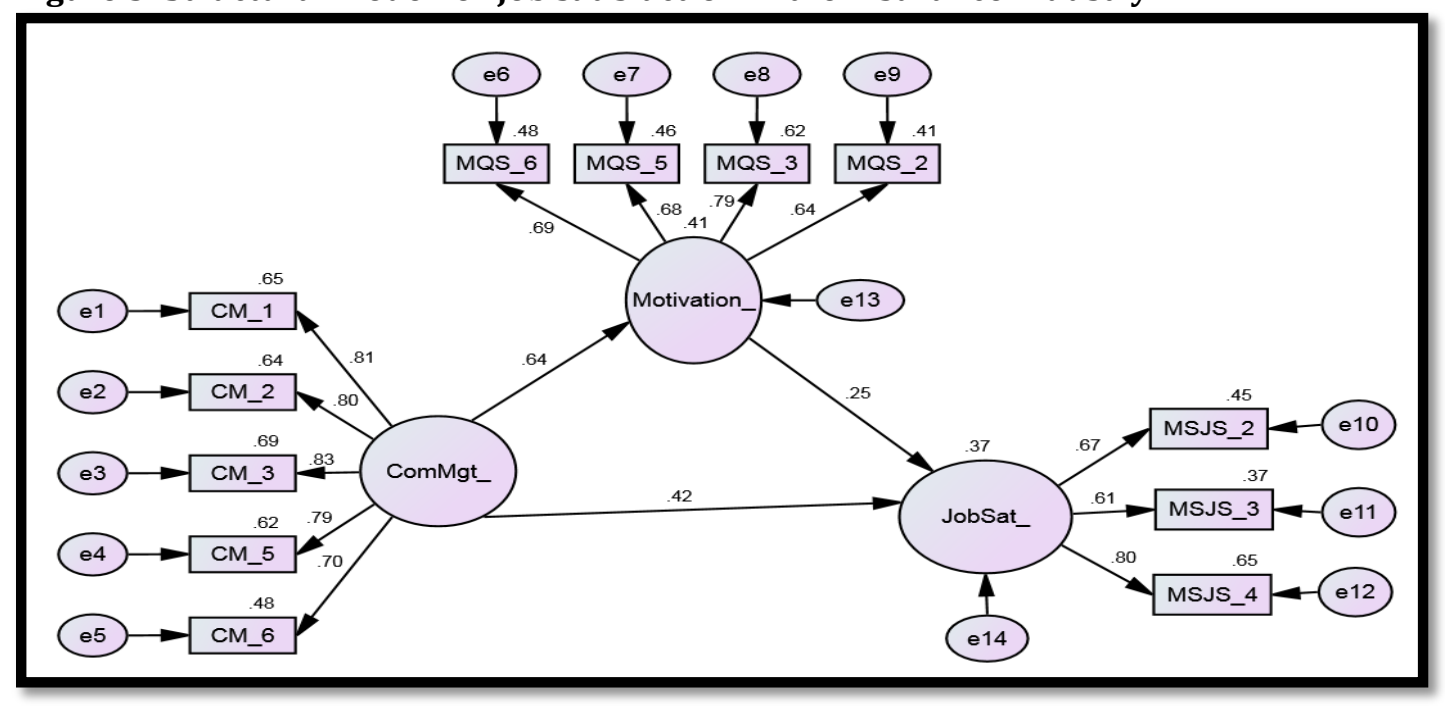

Chi-square $=124.181 ; \mathrm{DF}=51 ; \mathrm{p}$-value $=0.000(<0.001)$;

$\mathrm{CMIN} / \mathrm{DF}=2.435(<5) ; \mathrm{GFI}=0.916(>0.90)$;

$\mathrm{NFI}=0.912(>0.90) ; \mathrm{IFI}=0.936(>0.90) ; \mathrm{TLI}=0.916(>0.90) ; \mathrm{CFI}=0.935(>0.90)$; RMSEA $=0.072$ (below $0.08)$.

The model fit indices presented in Figure 2 are acceptable as all factor loadings ranged from 0.64 to 0.85 , significant at $\mathrm{p}<0.001$, which signified a statistical validity of the proposed model. Approximately 94\% (GFI = 0.937) of the variances and covariances of the proposed model could be explained by the collected data. The fit indices conform to the theoretical foundation of the three latent variables and their corresponding manifest variables included in the measurement model. This empirical model validates the theoretical assumptions with respect to influences of compensation administration and other motivating factors such as; promotion, company policy and developmental programme on workers satisfaction in the insurance industry. The structural model explaining the mutual influences of compensation management and motivation on employees' job satisfaction in the insurance industry is presented in Figure 4.

As is evident in the AMOS output presented in Figure 3, compensation management has strong, direct and different positive influences on motivation (0.64) and job satisfaction $(0.42)$ in the insurance industry. Motivation has a direct positive influence on job satisfaction (0.25). All regression weights were significant at $\mathrm{p}<0.001$. Drawing emphasis from the standardised regression weights, one can conclude that compensation management has a prominent but significant influence on employees' level of motivation in the insurance industry. Therefore, hypothesis one (H1) was empirically supported in this paper. Statistically, the result showed that motivation has a significant positive influence on job satisfaction in the insurance industry. Hypothesis two (H2) was also supported based on the findings of this paper. Evidently, the direct link from compensation management to job satisfaction explained a more significant influence on employees' job satisfaction than the indirect link through motivation. This supports hypothesis three (H3), meaning that compensation management has more direct positive impacts on employees' job satisfaction in the insurance industry. Therefore, financial rewards offered in the industry explained most of the variations in job satisfaction. Factors such as promotion, company policy, developmental programmes and equity in employees' pay explained fewer of the variations in job satisfaction within the industry. Employees derived more satisfaction from the financial rewards than the non-financial rewards offered by management. This result is not surprising; it corroborated the outcomes of a recent study conducted in a service industry (Bustamam, Teng, \& Abdullah, 2014) and also affirmed that financial reward has a stronger influence on job satisfaction when compared to a non-financial reward. 


\section{Managerial Relevance and Conclusion}

Managerial Relevance: Apart from the empirical and theoretical relevance of the current study, this paper also offers practical recommendations for the management in the insurance industry. Employees' job satisfaction was established as a fundamental antecedent to employees' performance as well as organisational outcomes in the insurance industry. This suggests that management should be concerned with issues hindering employees' job satisfaction. Pay offered by management (compensation management) explained most of the variations in employees' job satisfaction in the insurance industry, while other nonfinancial rewards put in place by management explained fewer of the variations in job satisfaction. This implies that employees derived less satisfaction with the company policies and developmental programmes, as well as the policy used in administering their promotions. Appropriate consideration should be given to issues of mutual interest at the developmental stage of the policies affecting employees' promotion. Other stakeholders' involvement at the developmental stage could improve the level of employees' job satisfaction in the insurance industry. Non-financial rewards as motivational tools could be used to improve employees' job satisfaction resulting in employees' productivity and business sustainability in the long run.

This paper aims to structurally determine employees' job satisfaction by investigating the mutual influences of compensation administration and motivation in the insurance industry. The multivariate data analysis (SEM) employed was to test the theoretical positions with respect to joint influence of reward administration and motivation on job satisfaction in the specified service industry. The results showed that compensation management and motivation significantly influenced employees' job satisfaction in the insurance industry. This result was confirmed using the model fit indices demonstrated below the measurement and structural models presented in Figure 2 and 3 respectively. The empirical result demonstrates that the models are closely fitted to the sample data. The hypotheses tested in this paper received empirical support, which could be used to maintain a balance between theory and practice (praxeology) in the insurance industry. The direct link from compensation management significantly contributed more to motivation, compared to the direct link from compensation management to job satisfaction in the industry. This means that compensation management had more prominent influence on employees' motivation than employees' job satisfaction. Statistically, this study found that compensation management exerts more direct influence on employees' job satisfaction than the indirect link through motivation. It could be said that motivation partially mediates the relationship between compensation management and employees' job satisfaction in the insurance industry. This paper concludes that financial rewards made greater contributions to the variations in employees' job satisfaction in the industry. Factors such as promotion, company policy and developmental programmes used to boost employees' morale contributed less to the levels of employees' job satisfaction in the insurance industry. Evidently, employees derived more satisfactions from pay received on the job, when compared to satisfactions from job empowerment and fulfilment. There may be a need to redesign human resource practices in order to improve the level of employees' satisfaction with job fulfilment in the industry.

Study Limitation: The thrust of this paper was limited to the structural determinants of work fulfilment in insurance industry, demonstrating mutual effect of compensation management plus motivation. A lack of multiple influences of compensation management, motivation and employees' job satisfaction on human resource/organisational outcomes was the greatest limitation of this paper. Future studies may be conducted on the gap identified in other sectors of the economy. As far as methodology is concerned, a combination of explanatory sequential mixed methods and a longitudinal approach may be more appropriate to investigate the cause and effect of compensation management and motivation on workers' employment contentment in insurance industry. Specifically, outcome of this paper is limited to relationships among remuneration administration, inspiration and job satisfaction in the insurance company in Nigeria. Therefore, caution should be taken before making generalisations based on the findings of this paper. The researchers has successfully tested theoretical propositions on the associations among compensation management, motivation and employees' job satisfaction with the practice in insurance industry utilising structural equation modelling.

Acknowledgement: This paper is based on a PhD study at the University of KwaZulu-Natal. Dr Fields was the supervisor of the study. 


\section{References}

Adams, J. S. (1965). Toward an Understanding of Inequity. Journal of Abnormal and Social Psychology, 67, 422436.

Adeoye, A. O. (2001). Contemporary Issues in Human Resources Management and Organisational Behaviour. Lagos, Nigeria: Pumark Publishers.

Adeoye, A. 0. (2014). An Assessment of Compensation Management and Motivation on Organisational Performance in the Insurance Industry in Nigeria. An Unpublished Doctoral Dissertation, University of KwaZulu-Natal, Durban, South Africa.

Adeoye, A. O. (2014). The Influence of Compensation Management and Employee's Leadership Role in Insurance Sector: Nigeria Experience. Mediterranean Journal of Social Sciences, 5(27), 342-352.

Adeoye, A. 0. \& Elegunde, A. F. (2014). Compensation Management and Motivation: Cooking Utensils for Organisational Performance. Mediterranean Journal of Social Sciences, 5(27), 88-97.

Adeoye, A. O. \& Fields, Z. (2014). Compensation Management and Employee Job Satisfaction: A Case of Nigeria. Journal of Social Sciences, 41(3), 345-352.

Ahlstrom, D. \& Bruton, G. D. (2010). International Management: Strategy and Culture in the Emerging World, London: South-Western, Cengage Learning, EMEA.

Ahmed, I., Nawaz, M. M., Iqbal, N., Ali, I., Shaukat, Z. \& Usman, A. (2010). Effects of Motivational Factors on Employees Job Satisfaction: A case study of University of the Punjab, Pakistan. International Journal of Business and Management, 5(3), 70-80.

Alderfer's, C. P. (1972). Existence, relatedness and growth, New York: Free Press.

Altindis, S. (2011). Job Motivation and Organisational Commitment among the Health Professionals: A Questionnaire Survey. African Journal of Business Management, 5(21), 8601-8609.

Amila-Prasanga, A. P. \& Gamage, A. S. (2012). Job Satisfaction and Job Performance of the Sailors in Rapid Action Boat Squadron of Sri Lanka Navy. Sri Lankan Journal of Human Resource Management, 3(1), 49-57.

Ayeni, C. O. \& Popoola, S. O. (2007). Work Motivation, Job Satisfaction and Organisational Commitment of Library Personnel in Academic and Research Libraries in Oyo State, Nigeria. Library Philosophy and Practice.

Armache, J. (2012). Effect of Compensation and Other Motivational Techniques on Organisational Performance. Franklin Business and Law Journal, 3(1), 88-96.

Arshadi, N. (2010). Basic Need Satisfaction, Work Motivation, and Job Performance in an Industrial Company in Iran. Procedia-Social and Behavioral Sciences, 5, 1267-1272.

Aydogdu, S. \& Asikgil, B. (2011). An Empirical Study of the Relationship among Job Satisfaction, Organisational Commitment and Turnover Intention. International Review of Management and Marketing, 1(3), 43-53.

Balachandan, G., Panchanathan, N. \& Subramanian, K. (2010). Impact of job satisfaction on the motivation of insurance company officers: a developmental perspective. International Journal of Trade, Economics and Finance, 1(4), 349-353.

Bob, N. (2011). Making Employees Suggestions Count. Journal of Personnel Management, 17, 20-41.

Brevis, T. \& Vrba, M. (2014). Contemporary Management Principles. South Africa: Juta and Company Ltd.

Brislin, R. W., Kabgting, F., Macnab, B., Zukies, B. \& Worthley, R. (2005). Evolving Perceptions of Japanese Workplace Motivation. International Journal of Cross Cultural Management, 5, 87-103.

Bustamam, F. L., Teng, S. S. \& Abdullah, F. Z. (2014). Reward Management and Job Satisfaction among Frontline Employees in Hotel Industry in Malaysia. Procedia - Social and Behavioral Sciences, 144, 392-402.

Celik, M., Man, M., Modrak, V., Dima, I. C. \& Pachura, P. (2011). A Theoretical Approach to the Job Satisfaction. Polish Journal of Management Studies, 4, 7-15.

Cruz, N. M., Pérez, V. M. \& Cantero, C. T. (2009). The Influence of Employee Motivation on Knowledge Transfer. Journal of Knowledge Management, 13(6), 478-490.

Davidson, J. (1898). The Bargain Theory of Wages. New York: GP Putnam's Sons.

Ederer, F. \& Manso, G. (2013). Is Pay for Performance Detrimental to Innovation? Management Science, 59(7), 1496-1513. 
Elisenberger, R. \& Aselage, J. (2009). Incremental Effects of Reward on Experienced Performance Pressure: Positive Outcomes for Intrinsic Interest and Creativity. Journal of Organisational Behaviour, 30(1), 95-117.

Eren, E. (1993). Management and Organisation. (2nd ed), Istanbul: Beta Basim Yayim Dağitim.

Feinstein, A. H. \& Vondrasek, D. (2000). A Study of Relationships between Job satisfaction and Organisational Commitment among Restaurant Employees (2013). Retrieved 17th July, 2013 from http://hotel.unlv.edu/pdf/job Satisfaction.pdf.

Govender, S. \& Parumasur, S. B. (2010). The relationship between employee motivation and job involvement. South African Journal of Economic and Management Sciences= Suid-Afrikaanse Tydskrif vir Ekonomiese en Bestuurswetenskappe, 13(3), 237-253.

Greenberg, J. \& Baron, R. A. (2000). Behaviours in Organisations (7th ed), New Jersey: Prentice Hall.

Grobler, P. A., Wärnich, S., Carrell, M. R., Elbert, N. F. \& Hatfield, R. D. (2011). Human Resource Management in South Africa (4th ed), UK: Cengage Learning EMEA.

Gummi, A. S. (2011). Impact of Global Financial Crisis on Job Satisfaction of Employees of Nigerian Banks. International Journal of Social Sciences and Humanities Review, 2(2), 14-18.

Haque, M., Karim, A. N. M., Muqtadir, A. \& Anam, S. (2012). Dimensions of job satisfaction of library professionals: a qualitative exploration. International Journal of Business and Social Research, 2(5), 46-62.

Herzberg, F. (1966). Work and the Nature of Man. Clevelland: World.

Hewitt, A. (2009). Managing Performance with Incentive Pay. Journal of Personnel Management, 7(1), 20-31.

Hills, P. S., Bergmann, T. J. \& Scarpello, V. G. (1994). Compensation Decision Making (2nd ed), New York: The Dryden Press.

Ivancevich, J. M. \& Matteson, M. T. (1990). Organisational Behaviour and Management (2nd ed), Boston: Bpi Irwin.

Jensen, M. C. (1994). Self-Interest, Altruism, Incentives and Agency Theory. Journal of Applied Corporate Finance, 7(2), 1-17.

Kim, J. Y., Shim, J. P. \& Ahn, K. M. (2011). Social Networking Service: Motivation, Pleasure, and Behaviour Intention to use. Journal of Computer Information System, 3, 92-101.

Kulkarni, M. (2011). Revisiting Maslow the "IT" Way: A Case Study. International Conference on Management (ICM 2011) proceedings, 48-57.

Kreitner, R. \& Kinicki, A. (1998). Organizational Behaviour (4th ed), McGraw Hill/Irwin.

Larson, M. D., Latham, J. R., Appleby, C. A. \& Harshman, C. L. (2012). CEO Attitudes and Motivations: Are They Different for High-Performing Organisations? Quality Management Journal, 19(4), 55-69.

Lee, M. K. O., Cheung, C. M. K. \& Chen, Z. (2005). Acceptance of Internet-Based Learning Medium: The Role of Extrinsic and Intrinsic motivation. Journal of Information and Management, 42(8), 1095-1104.

Lee, C. \& Way, K. (2010). Individual Employment Characteristics of Hotel Employees that Play a Role in Employee Satisfaction and Work Retention. International Journal of Hospitality Management, 29, 344353.

Lin, H. F. (2007). Effects of Extrinsic and Intrinsic Motivation on Employee Knowledge Sharing Intentions. Journal of Information Science, 33(2), 135-149.

MacCallum, R. C., Widaman, K. F., Zhang, S. \& Hong, S. (1999). Sample Size in Factor Analysis. Psychological methods, 4(1), 84-99.

Mahaney, C. R. \& Lederer, A. L. (2006). The Effect of Intrinsic and Extrinsic Rewards for Developers on Information Systems Project Success. Project Management Journal, 37(4), 42-54.

Manolopoulos, D. (2008). An Evaluation of Employee Motivation in the Extended Public Sector in Greece. Employee Relations, 30(1), 63-85.

Mathauer, I. \& Imohoff, I. (2006). Health Worker Motivation in Africa: The Role of Non-Financial Incentives and Human Resource Management Tools. Human Resources for Health, 4(24). [Downloaded: http://www.human-resource-health.com/content/2011/11/24].

Mathis, R. L. \& Jackson, J. H. (2011). Human Resource Management (13th ed), USA: South-Western Cengage Learning

Maslow, A. H. (1943). A Theory of Human Motivation. Psychological Review, 50, 394-395.

Mayo, E. (1930). The Human Effect of Mechanisation. American Economic Review: Papers and proceedings 20, 156-176. 
Milkovich, G. T. \& Newman, J. M. (1999). Compensation (6th ed), New York: McGraw Hill.

Milkovich, G. T., Newman, J. M. \& Gerhart, B. (2011). Compensation (10th International ed), New York: McGraw Hill.

Mitchell, T. R. (1982). Motivation: New Direction for Theory, Research, and Practice. Academy of Management Review, 7(1), 80-88.

Morrell, D. L. (2011). Employee Perceptions and the Motivation of Nonmonetary Incentives. Compensation and Benefits Review, 43(5), 318-323.

Mottaz, J. C. (1985). The Relative Importance of Intrinsic and Extrinsic Rewards as Determinants of Work Satisfaction. The Sociological Quarterly, 26(3), 365-385.

Pallant, J. (2011). SPSS Survival Manual: A Step by Step Guide to Data Analysis using SPSS (4th ed), Australia: Allen and Unwin.

Porter, L. W. \& Lawler III, E. E. (1968). Managerial Attitudes and Performance. Homewood: Irwin.

Qureshi, M. (2013). Relationship between Rewards and Employee Motivation in Administration Block of Punjab University. International Journal of Innovative and Applied Finance, 2, 1-13.

Ramlall, S. (2004). A Review of Employee Motivation Theories and their Implications for Employee Retention within Organisations. Journal of American Academy of Business. Cambridge, 5(1\&2), 52-63.

Rashid, U., Wani, N. A. \& Kumar, F. A. (2013). Difference in Job Satisfaction and Work Motivation among Government and Private Company Employees. International Journal of Innovative Research and Development, 2(7), 143-148.

Riddell, C. (2011). Compensation Policy and Quit Rates: A Multilevel Approach using Benchmarking Data. Industrial Relations: A Journal of Economy and Society, 50(4), 656-677.

Seiler, S., Lent, B., Pinkowska, M. \& Pinazza, M. (2011). An Integrated Model of Factors Influencing Project Managers' Motivation-Findings from a Swiss Survey. International Journal of Project Management, doi: 10.1016/j.ijproman.2011.03.002.

Shaw, J. D. (2014). Pay Dispersion. The Annual Review of Organisational Psychology and Organisational Behaviour, 2014(1), 521-544.

Stringer, C., Didham, J. \& Theivananthampillai, P. (2011). Motivation, Pay Satisfaction, and Job Satisfaction of Front-Line Employees. Qualitative Research in Accounting and Management, 8(2), 161-179.

Tella, A., Ayeni, C. 0. \& Popoola, S. 0. (2007). Work Motivation, Job Satisfaction, and Organizational Commitment of Library Personnel in Academic and Research Libraries in Oyo State, Nigeria. Library Philosophy and Practice, 3, 1-16.

Vroom, V. H. (1964). Work and Motivation, New York: Wiley.

Walker, C. O., Greene, B. A. \& Mansell, R. A. (2006). Identification with Academics, Intrinsic/Extrinsic Motivation, and Self-Efficacy as Predictors of Cognitive Engagement. Learning and Individual Differences, 16(1), 1-12.

Weiss, D. J., Davis, R. V., England, G. W. \& Lofquist, L. H. (1967). Manual for the Minnesota Satisfaction Questionnaire. Minnesota: IRC. University of Minnesota.

Wininger, S. R. \& Norman, A. D. (2010). Assessing Coverage of Maslow's Theory in Educational Psychology Textbooks: A Content Analysis. Teaching Educational Psychology, 6(1), 33-48. 